\title{
Barrier Function Regulates Epidermal DNA Synthesis
}

\author{
Ehrhardt Proksch, "* Kenneth R. Feingold,' Man Mao-Qiang, * and Peter M. Elias* \\ ${ }^{* \neq}$ Dermatology, and ${ }^{\$}$ Medicine Services, Veterans Administration Medical Center and University of California School of Medicine, \\ San Francisco, California 94121; and ${ }^{\ddagger}$ Dermatology Clinics, University of Goettingen, Goettingen, Germany
}

\begin{abstract}
We examined the possibility that the cutaneous permeability barrier regulates epidermal DNA synthesis in two acute and two chronic models of barrier perturbation. In animals treated topically with acetone, DNA synthesis is increased $102 \%$, in tape-stripped animals $127 \%$, in essential fatty acid deficient animals $50 \%$, and in animals chronically treated with topical lovastatin $64 \%$. This linkage between disturbances in barrier function and increased DNA synthesis is further supported by specific and correlative observations: $(a)$ in these disparate models, artificial replacement of the barrier with a water-impermeable membrane inhibits the expected increase in DNA synthesis; (b) the extent of the burst in DNA synthesis is proportional to the degree of barrier abrogation; (c) the inhibition of DNA synthesis by membranes is directly related to the degree of permeability of these occlusive membranes, i.e., the more impermeable the greater the degree of inhibition; $(d)$ topical treatment with lipids that restore barrier function corrects the increase in DNA synthesis; and (e) barrier abrogation with acetone produces an increase in epidermal DNA synthesis without altering bulk protein synthetic rates in contrast to events known to follow injury or cell replacement. Autoradiographic studies show that the increase in DNA synthesis after acetone treatment is limited to the epidermal basal layer. This constellation of findings strongly suggests that cutaneous barrier function is one factor that regulates epidermal DNA synthesis. (J. Clin. Invest. 1991.87:1668-1673.) Key words: permeability barrier • transcutaneous water loss • epidermal hyperplasia • epidermal DNA synthesis
\end{abstract}

\section{Introduction}

The main function of the skin is to generate an external layer, the stratum corneum, which separates the internal and external milieu of the organism. The stratum corneum is organized into a heterogeneous two-compartment system of protein-enriched cells embedded within an intercellular matrix enriched in hydrophobic lipids, organized into extensive lamellar sheets, which are thought to regulate epidermal barrier function (reviewed in 1,2). Previous studies have shown that various perturbations in epidermal barrier function, including topical applications of organic solvents, detergents, or in essential fatty acid deficiency (EFAD), ${ }^{1}$ induce a transient burst of lipid syn-

Address correspondence to Dr. Peter M. Elias, Dermatology Service (190), Veterans Administration Medical Center, 4150 Clement Street, San Francisco, CA 94121.

Received for publication 7 June 1990 and in revised form 27 December 1990.

1. Abbreviations used in this paper: EFAD, essential fatty acid deficiency; TEWL, transepidermal water loss.

The Journal of Clinical Investigation, Inc.

Volume 87, May 1991, 1668-1673 thesis limited to the underlying epidermis, which leads to lipid replenishment of the stratum corneum and a return of barrier function to control levels (3-6). Occlusion with a water vapor impermeable membrane prevents the increase in epidermal lipid synthesis, the replenishment of stratum corneum lipids, and the return of barrier function (3-5). These studies led to the conclusion that the integrity of the permeability barrier is maintained by modulations in epidermal lipid biosynthesis.

On the other hand, in several model systems, such as tapestripping (7-10) or in EFAD (11-13), abnormal barrier function is known to be accompanied by epidermal hyperplasia. Whereas such hyperplasia is generally assumed to represent either a nonspecific response to injury or a requirement for cell replacement (e.g., 14-19), we noted incidentally that even acetone treatment, which is not accompanied by histological evidence of epidermal injury or cell removal, also appears to provoke histologic evidence of epidermal hyperplasia. This observation prompted us to search for a direct link between barrier function and epidermal DNA synthesis.

\section{Methods}

Experimental design. Acute disruption of the permeability barrier was achieved by: (a) unilateral treatment of hairless mice $(\mathrm{Hr} / \mathrm{Hr}$, Jackson Laboratory, Bar Harbor, ME) with absolute acetone, while the contralateral (control) side was treated with an equivalent number of applications of $0.9 \%$ sodium chloride alone (3-5); and (b) successive applications of cellophane tape (Scotch-type). Both methods produced greatly elevated transepidermal water loss (TEWL) levels (Table I), measured with an electrolytic water analyzer (Meeco, Warrington, PA), indicative of barrier disruption (3-6). Some groups of treated and control (saline-treated) animals were occluded with either a tightly fitted, water vapor-impermeable, Latex membrane, partially vapor-impermeable wraps (Op-Site, Duoderm), or a vapor-permeable foil (GoreTex) for 20 h (5). To examine the effects of occlusion for different times we occluded groups of mice with a Latex wrap from time point zero to time point $\mathrm{X}$ or from time point $\mathrm{X}$ to $20 \mathrm{~h}$; all experiments were terminated after $20 \mathrm{~h}$. Chronic barrier disruption (TEWL levels $>100 \mathrm{ppm} / 0.5$ $\mathrm{cm}^{2} / \mathrm{h}$ ) was achieved by feeding animals an EFAD vs. control diet for 7-8 wk (20), followed by occlusion of some animals, as described above. Additional groups of EFAD animals were treated unilaterally with five daily applications of either linoleic acid, columbinic acid (C18:3;n-6, 9, 13-trans, a gift from Dr. A. Houtsmuller Unilever Res. The Netherlands), $\mathrm{PGE}_{2}(150 \mu \mathrm{g} / \mu \mathrm{l}$ of the methyl ester of each lipid in ethanol:propylene glycol [3:7] vehicle/1 $\mathrm{cm}^{2}$ ), or vehicle alone (fatty acids were from Sigma Chemical Co., St. Louis, MO). Columbinic acid has been previously shown to correct barrier function in these animals without prior conversion to prostaglandins $(21,22)$, the putative regulators of hyperplasia in EFAD epidermis (23-25). In our studies both linoleic and columbinic acid treatment improved barrier function (TEWL $<40 \mathrm{ppm} / 0.5 \mathrm{~cm}^{2} / \mathrm{h}$ ). Chronic barrier disruption also occurred following $7 \mathrm{~d}$ of topical treatment with lovastatin, an inhibitor of cholesterol synthesis. The lovastatin was a gift from Dr. A. Alberts, Merck, Sharpe \& Dohme, Inc., Rahway, NJ, and was applied (30 $\mu$ ) once daily to a $2-\mathrm{cm}^{2}$ area on one flank. The lovastatin solution ( 25 $\mathrm{mg} / \mathrm{ml}$ ) was solubilized in propylene glycol:ethanol (7:3 vol) immediately before application. Vehicle alone was applied daily to one flank of a separate group of animals. Occlusion of some lovastatin- and vehicle- 
treated animals ( $n=4$ each) with a water impermeable membrane was carried out for $24 \mathrm{~h}$, as described above.

DNA synthesis measurements. Each animal received an intraperitoneal injection of $30 \mu \mathrm{Ci}$ [methyl $\left.-^{3} \mathrm{H}\right]$ thymidine (New England Nuclear, Boston, MA) diluted in $300 \mu \mathrm{l}$ saline $1 \mathrm{~h}$ before killing. Skin samples (2 $\mathrm{cm}^{2}$ ) were removed from both the treated and control sides, scraped free of excess subcutaneous fat, and the epidermis separated from the dermis by incubation in a $10-\mathrm{mM}$ EDTA solution at $37^{\circ} \mathrm{C}$ for $40 \mathrm{~min}$ (2). Epidermal sheets were weighed, minced, and homogenized in distilled water with a tissue homogenizer (Polytron; Kinematica BmbH, Lucerne, Switzerland), followed by homogenization with a Sonic Dismembranator (Fisher Scientific Co., Pittsburgh, PA). $1 \mathrm{ml}$ of cold $10 \%$ TCA then was added to the homogenate. $10 \mathrm{~min}$ later the material was centrifuged at $2,000 \mathrm{~g}$ at $4^{\circ} \mathrm{C}$ for $5 \mathrm{~min}$. The supernatant was discarded and the precipitant material washed two times with $500 \mu \mathrm{l}$ of $5 \%$ cold TCA followed by centrifugation. The precipitated material was then suspended in $400 \mu \mathrm{l}$ of $5 \% \mathrm{TCA}$, heated in a water bath at $90^{\circ} \mathrm{C}$ for 15 $\mathrm{min}$, and centrifuged. Aliquots (duplicates) of the supernatant containing the hydrolyzed DNA were counted by liquid scintillation. DNA content was determined with the diphenylamine reagent (Sigma) (26).

Protein synthesis measurements. At the times indicated after acetone treatment the mice were killed and skin from the treated and saline control flanks were removed. Each skin sample was incubated for $2 \mathrm{~h}$ at $37^{\circ} \mathrm{C}$ in $2 \mathrm{ml}$ of keratinocyte growth medium (27), containing $20 \mu \mathrm{Ci}$ of $\left.{ }^{35} \mathrm{~S}\right] \mathrm{methionine.} \mathrm{After} \mathrm{incubations} \mathrm{the} \mathrm{epidermis} \mathrm{was} \mathrm{isolated}$ by heat treatment $\left(60^{\circ} \mathrm{C}\right.$ for $\left.60 \mathrm{~s}\right)$, as described previously (3-6). The epidermal samples were homogenized and the incorporation of radiolabel into protein was determined following TCA precipitation, as described above. Total protein was determined using a BCA protein assay reagent (Pierce Chemical Co., Rockford, IL).

Microscopy and autoradiography. Biopsies were taken for: (a) light microscopy (hematoxylin and eosin staining) of the skin of acetone treated, and control sites immediately after and $24 \mathrm{~h}$ after treatment and $(b)$ autoradiography $2 \mathrm{~h}$ after intradermal administration of [ methyl $-{ }^{3} \mathrm{H}$ ] thymidine $(30 \mu \mathrm{Ci}$ diluted in $30 \mu \mathrm{l}$ normal saline) and $22 \mathrm{~h}$ after acetone treatment.

Statistical significances were determined using either a two-tailed or paired Student's $t$ test.

\section{Results}

To determine whether the proliferation that occurs after tape stripping is a nonspecific response to injury, cell replacement, altered cellular metabolism, or whether it occurs as a result of barrier perturbation, we compared both barrier recovery and DNA synthesis after barrier disruption by tape-stripping in unoccluded vs. occluded animals. Tape-stripping resulted in a marked increase in TEWL (Table I). Over time, TEWL decreased so that by $28 \mathrm{~h}$ TEWL rates were $95 \pm 25 \mathrm{ppm} / 0.5 \mathrm{~cm}^{2} /$ $h$ in air-exposed animals. In contrast, in tape-stripped animals

Table I. Permeability Barrier Function and Peak DNA Synthesis in Acute Models

\begin{tabular}{|c|c|c|}
\hline Condition & $\begin{array}{l}\text { Transepidermal } \\
\text { water loss }\end{array}$ & $\begin{array}{c}\text { Peak DNA } \\
\text { synthesis }\end{array}$ \\
\hline & $p p m / 0.5 \mathrm{~cm}^{2}$ per $h$ & $h$ \\
\hline Control & $<20$ & - \\
\hline \multicolumn{3}{|l|}{ Acute } \\
\hline Tape-stripped ${ }^{*}$ & $667 \pm 144$ & 18 \\
\hline Acetone* & $890 \pm 80$ & 20 \\
\hline
\end{tabular}

* Transepidermal water loss was measured immediately after barrier disruption $(0.1 \mathrm{~h})$, with an electrolytic water analyzer (3-5). occluded with an impermeable Latex wrap TEWL did not decrease; TEWL levels were still markedly elevated after $20 \mathrm{~h}$. This confirms previous studies in the acetone model (5) demonstrating that barrier function does not recover when an artificial barrier is provided. Similar to observations reported by others (7-10), tape-stripping produced a $127 \%$ increase in DNA synthesis $18 \mathrm{~h}$ after treatment. Most importantly, this increase was greatly reduced by artificial restoration of barrier function by occlusion (Fig. $1 \mathrm{~A}$ ). Thus, in two acute models of barrier disruption, artificial provision of a barrier diminishes both barrier repair and the increase in DNA synthesis.

As with tape-stripping, acetone treatment stimulated DNA synthesis, reaching a maximum of $102 \pm 11 \%$ over control at 20 h (Fig. 1 B). Moreover, artificial restoration of barrier function by occlusion with a water-impermeable membrane largely blocked the expected increase in DNA synthesis (Fig. $1 B$ ). In contrast to the impermeable membrane, occlusion with a largely water vapor-permeable membrane (Goretex) produced only a slight decrease in the expected burst in DNA synthesis (Latex: 75\% inhibition; Goretex: 25\% inhibition). As described in detail previously, occlusion with a vapor-impermeable membrane prevents the characteristic repair of the barrier that occurs in response to acetone treatment, whereas occlusion with a vapor-permeable membrane does not (5). Occlusion of control sites for comparable time periods did not alter DNA synthesis (control: $6.21 \pm 0.43$ vs. Latex-covered control: $6.71 \pm 0.82 \mathrm{cpm} / \mu \mathrm{g}$ DNA/h; NS). Finally, the extent of the increase in DNA synthesis correlated directly with the degree of barrier disruption in both acetone and tape stripping models, i.e., the more extensive the degree of barrier disruption, the greater the burst in DNA synthesis (acetone: Fig. $2, r=0.94 ; P$ $<0.01$; tape-stripping: Fig. $3, r=0.91 ; P<0.01$ ).

In contrast to the burst in DNA synthesis that follows acetone treatment, no significant changes were observed in bulk
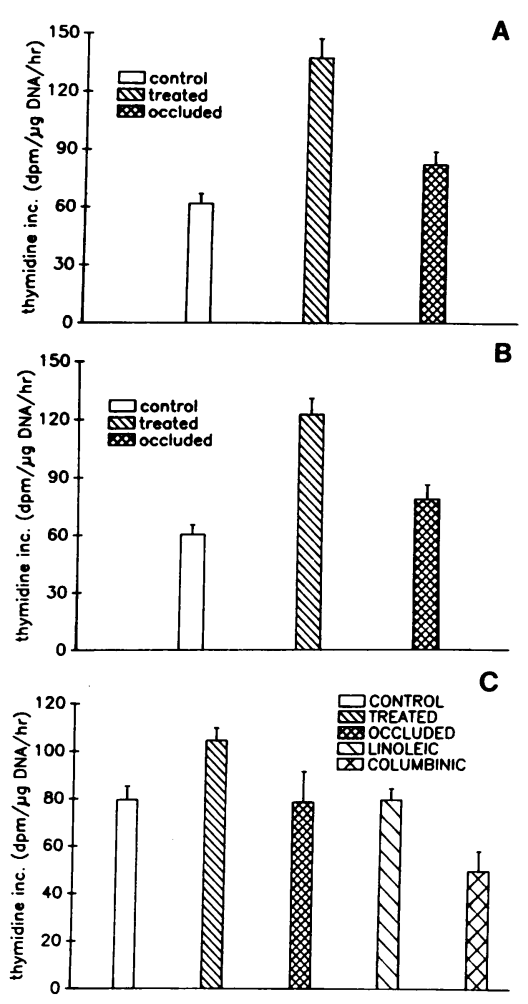

Figure 1. Panels $A$ and $B$ show DNA synthesis 18-20 $\mathrm{h}$ after acute perturbations with tape stripping $(A)$ or acetone $(B)$ treatment alone and with such treatment followed by occlusion with Latex wrap (3-5). Panel $C$ shows DNA synthesis in essential fatty acid deficient mice $18 \mathrm{~h}$ after occlusion with a Latex occlusive wrap for $48 \mathrm{~h}$ or after five daily topical applications of either topical linoleic acid or columbinic acid (see text). 
Figure 2. Correlation of degree of barrier perturbation (transepidermal water loss) immediately following acetone treatment, and the extent of the increase in DNA synthesis at $18 \mathrm{~h}$. A linear relationship is apparent $(r=0.94)$ and highly significant $(P$ $<0.01$ ).

protein synthesis at various points after acetone treatment (1-3 h: $110 \pm 9.2 \%, 4-6 \mathrm{~h}: 106 \pm 15.7$ and $20-22 \mathrm{~h}: 131 \pm 13 \%$ of control, all NS). These results demonstrate that the burst in epidermal DNA synthesis is not accompanied by a parallel increase in protein synthesis.

As a further test of the role of barrier function in the regulation of DNA synthesis, we next compared DNA synthesis in acetone-treated mice covered with four different, tightly fitting wraps of varying permeability. As previously reported (5), the water vapor-impermeable, Latex wrap completely restored barrier function, while in contrast occlusion with the partially vapor-permeable wraps, Op-Site and Duoderm, and with the vapor-permeable wrap, Goretex, resulted in varying degrees of barrier restoration. The increase in DNA synthesis following acetone disruption of the barrier correlated with the known permeability properties of the various occlusive dressings (Fig. 4).

The next series of experiments were designed to determine the effect of occlusion with impermeable membranes for varying intervals on DNA synthesis. Acetone treatment produced an $81 \%$ increase in DNA synthesis and Latex occlusion from immediately after treatment ( 0 time) to the end of the experiment $(20 \mathrm{~h})$ reduced this increase to $34 \%$ (Table II). Occlusion from 0 to $13 \mathrm{~h}$ did not prevent the increase in DNA synthesis, but prolongation of occlusion to $16 \mathrm{~h}$ was partially inhibitory (54\% increase). These results demonstrate that occlusion for $>13 \mathrm{~h}$ is required to prevent the stimulation of DNA synthesis.

To gain further insights into the effects of barrier disruption on DNA synthesis, animals were occluded from 4 to 20,7 to 20 , and 10 to $20 \mathrm{~h}$. As shown in Table II, occlusion beginning at either 7 or $10 \mathrm{~h}$ had no effect on the subsequent burst in DNA

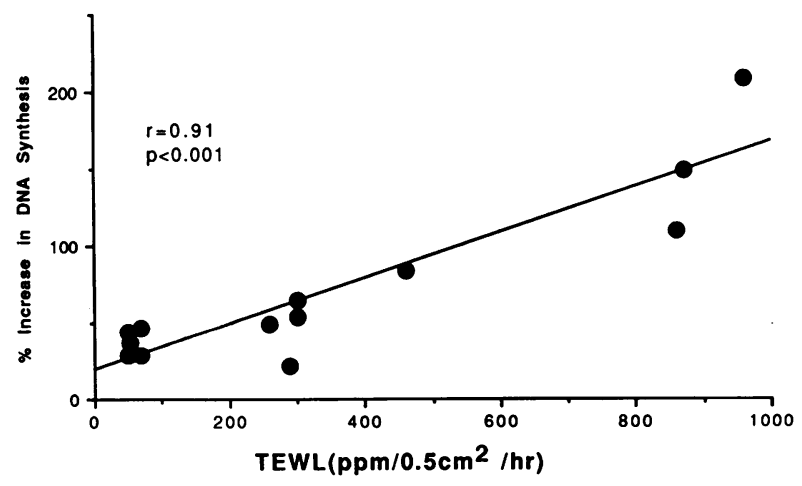

Figure 3. Correlation of degree of barrier perturbation (transepidermal water loss) immediately after tape stripping and the extent of the increase in DNA synthesis at $20 \mathrm{~h}$. A linear relationship is apparent $(r=0.91)$ and highly significant $(P<0.01)$.

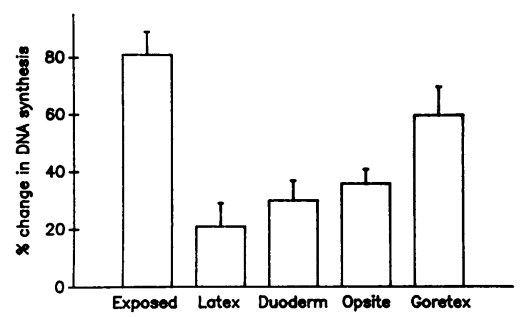

Figure 4. Prevention of expected burst in DNA synthesis in acetonetreated mice by occlusion with vapor-impermeable (Latex), partially vapor-permeable (Opsite, Duoderm), and vapor-permeable (Goretex) membranes. The

extent of increase in DNA synthesis is proportional to their ability to impede passage of water (TEWL data not shown; see 5).

synthesis. In contrast, animals occluded from 4 to $20 \mathrm{~h}$ displayed a slight decrease in DNA synthesis, which did not achieve statistical significance.

In EFAD animals, who display chronic disruption of barrier function, epidermal DNA synthesis was increased by $\approx 50 \%$ vs. normal (Fig. $1 C$ ). Once again, this increase in DNA synthesis was reversed by occlusion with a vapor-impermeable wrap. Moreover, topical replenishment with either linoleic acid or columbinic acid, both of which normalized barrier function (data not shown), reduced DNA synthesis (Fig. $1 C$ ), while topical $\mathrm{PGE}_{2}$ did not change TEWL rates, and produced only a modest change in DNA synthesis (EFA + vehicle: 112.8 \pm 6.7 vs. EFA + $\mathrm{PGE}_{2}: 102.2 \pm 6.6$; NS).

Repeated topical applications of lovastatin to hairless mouse skin also produced a progressive defect in barrier function. By $7 \mathrm{~d}$, TEWL rates were increased over vehicle-treated, control sites (control: $12 \pm 2$ vs. lovastatin: $410 \pm 64 \mathrm{ppm} / 0.5$ $\mathrm{cm}^{2} / \mathrm{h} ; P<0.01$ ). This change in barrier function was accompanied by a $64 \%$ increase in DNA synthesis over control sites. Occlusion for $24 \mathrm{~h}$ resulted in a $24 \%$ decrease in DNA synthesis in the lovastatin-treated animals. These results demonstrate the relationship of barrier function and epidermal DNA synthesis in two chronic models of barrier dysfunction.

As previously reported (3), the histology of acetone-treated epidermis revealed an intact stratum corneum with no evidence of epidermal injury (not shown). At $24 \mathrm{~h}$, a slight increase was evident in the number of nucleated cell layers, a finding that was accompanied by increased incorporation of $\left[{ }^{3} \mathrm{H}\right]$ thymidine limited to the basal cell layer (Fig. 5). In vehicle-

Table II. Effects of Latex Occlusion on DNA Synthesis after Acetone Treatment

\begin{tabular}{lc}
\hline \multicolumn{1}{c}{ Duration of occlusion } & $\begin{array}{c}\text { Increase in DNA } \\
\text { synthesis }\end{array}$ \\
\hline & $\pm S E M$ \\
No occlusion & $81 \pm 8 \%$ \\
Occlusion immediately after disruption & \\
Occlusion $0-20 \mathrm{~h}$ & $34 \pm 9 \%^{*}$ \\
Occlusion $0-16 \mathrm{~h}$ & $59 \pm 10 \%^{*}$ \\
Occlusion $0-13 \mathrm{~h}$ & $87 \pm 9 \%$ \\
Occlusion at various time points after disruption & \\
Occlusion $4-20 \mathrm{~h}$ & $68 \pm 8 \%^{\ddagger}$ \\
Occlusion $7-20 \mathrm{~h}$ & $83 \pm 8 \%$ \\
Occlusion $10-20 \mathrm{~h}$ & $86 \pm 10 \%$ \\
\hline
\end{tabular}

${ }^{*} P<0.05 ;{ }^{\ddagger} \mathrm{NS}$. 


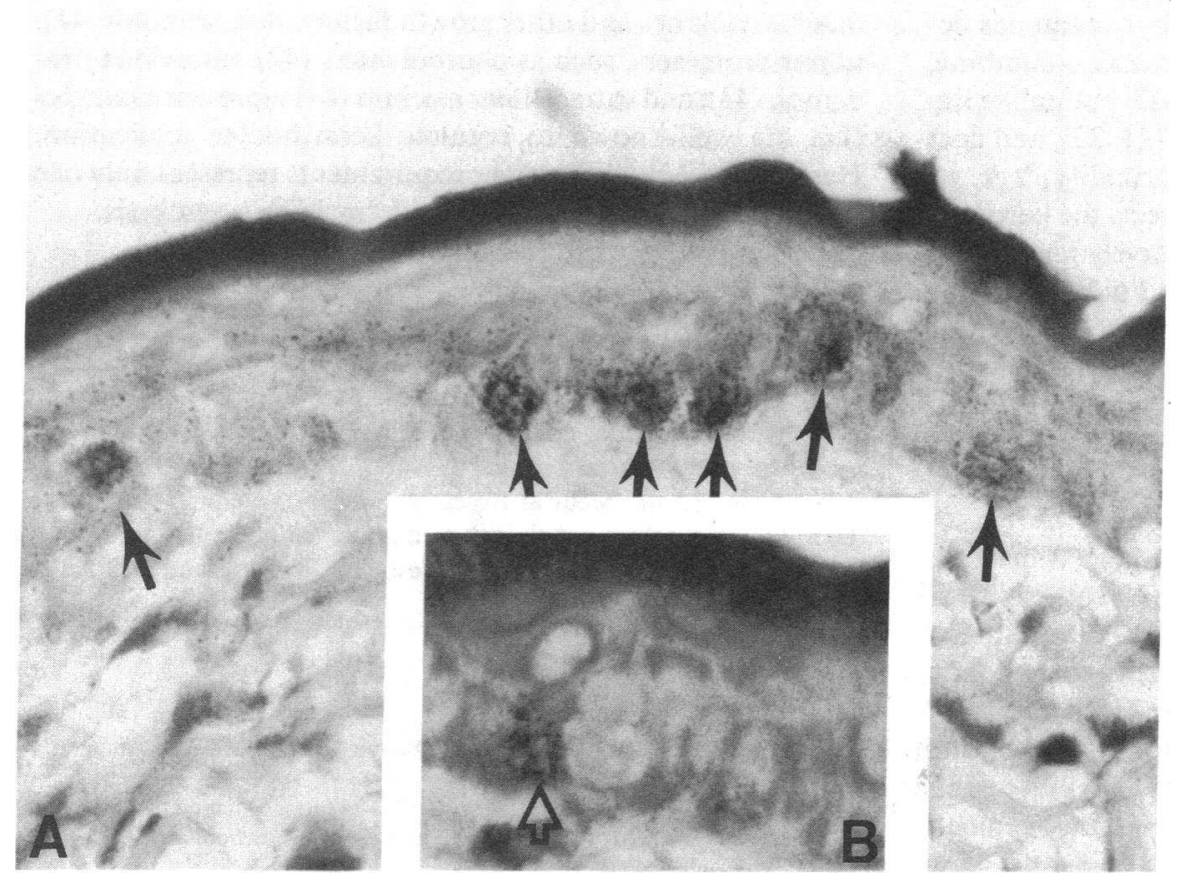

Figure 5. Autoradiogram of acetone-treated $(A)$ vs. vehicle-treated $(B)$ epidermis. Note increased numbers of basal cells taking up label in acetone treated animals, and that incorporation is limited to the basal layer. treated animals $14.3 \%$ of the basal cells were labeled, while in the acetone-treated animals $43.5 \%$ of the cells were labeled.

\section{Discussion}

The suggestion that barrier function is linked to epidermal DNA synthesis is not new $(9,10)$. Yet, despite this previous work, the potential relationship of barrier function and epidermal DNA synthesis has been largely overlooked; in current text books and comprehensive review articles the earlier suggestion that barrier requirements might regulate epidermal DNA synthesis is ignored. Instead, it is generally assumed that cell replacement, i.e., desquamation, is the principal regulator (1419). It is likely that because the earlier studies $(9,10)$ used tape-stripping as the sole model, the observations linking barrier dysfunction to epidermal DNA synthesis were ascribed to cell injury or the need for cell replacement rather than barrier function.

Our results mandate reexamination of this issue since our experiments clearly demonstrate in four different experimental models that increases in epidermal DNA synthesis are associated with a perturbed barrier. In animals treated topically with acetone, DNA synthesis increased $102 \%$, in tape-stripped animals $127 \%$, in EFAD animals 50\%, and in animals treated chronically with topical lovastatin $64 \%$. However, in each of these models alternative explanations, other than disturbances in barrier function, could be advanced to account for the increase in DNA synthesis. For example, in the tape-stripped model cell replacement can be invoked, while in the acetone model cellular injury could be a factor despite the absence of histologic evidence of cytotoxicity (3). In EFAD animals, nutritional deficiency leads to a paucity of cell regulatory eicosanoids $(23,24)$, and this could be an alternate cause for epidermal hyperplasia. However, it is noteworthy that in each of these disparate models, artificial replacement of the barrier by occlusion with a water vapor-impermeable wrap inhibited the ex- pected increase in DNA synthesis. However, it is unlikely that occlusion would correct each of the potential, alternate causes for increased DNA synthesis that might coexist in each of these models. Rather, it seems more likely that it is the perturbation in barrier function in these models that stimulates DNA synthesis, and this abnormality is corrected by occlusion with vaporimpermeable membranes. It is important that occlusion per se is not the explanation for this decrease because in animals with a normal barrier DNA synthesis is not altered by prolonged occlusion. Moreover, occlusive membranes that are permeable to water vapor produce only moderate decreases in the expected burst of DNA synthesis suggesting that the inhibition is not a nonspecific effect of occlusion. Furthermore, even these moderate decreases in DNA synthesis with water vapor-permeable membranes can be explained by the partial ability of these membranes to modulate rates of transcutaneous water loss (5).

Further evidence for a specific relationship between barrier function and epidermal DNA synthesis comes from several other observations. First, the response to acetone treatment is limited to DNA synthesis; no change occurs in bulk protein synthesis at comparable time points. Since protein denaturation is an obligate component of most forms of acute epidermal injury (28), one would expect a repair response, reflected by increased protein synthesis, if acetone treatment had caused substantial injury. Thus, the absence of a protein response, coupled with a significant burst in DNA biosynthesis, further points to the link between barrier homeostasis and DNA synthesis. Second, the extent of the burst in DNA synthesis is proportional to the degree of barrier abrogation induced by either acetone treatment or tape stripping. Third, the inhibition of DNA synthesis by membranes is directly related to the degree of permeability of these membranes to water vapor; i.e., the more impermeable the greater the inhibition. Fourth, the observation that topical treatment with linoleic acid and columbinic acid in EFAD animals corrects both the barrier defect and the increase in DNA suggests a specific relationship. 
Previously, the hyperplasia in EFAD has been ascribed to a failure to generate $\mathrm{PGE}_{2}$ and other regulatory eicosanoids derived from linoleic acid $(23,24)$. Like linoleic acid, columbinic acid corrects the barrier abnormality in EFAD, but unlike linoleic acid it cannot be metabolized to $\operatorname{PGE}_{2}(21,22)$, and does not correct the underlying metabolic abnormality. Yet, we have confirmed that this agent not only corrects the barrier in EFAD animals $(21,22)$, but also that it effectively reverses the accelerated rate of DNA synthesis. Moreover, lipids that do not correct barrier function ( $\left.\mathrm{PGE}_{2}\right)$ do not inhibit DNA synthesis. Thus, these experiments not only help to dispel the notion that the barrier defect in EFAD is due to hyperplasia, but they also demonstrate the reverse; i.e., that the increase in epidermal DNA synthesis in this model is largely a response to barrier disruption, just as in the acute models.

Finally, the simultaneous occurrence of both a defect in barrier function and increased epidermal DNA synthesis also is observed in animals treated topically for several days with lovastatin. We have recently reported that repeated applications of lovastatin, a potent inhibitor of hydroxymethyl-glutaryl CoA reductase (29), to intact skin produces a progressive defect in barrier function (30). Since lovastatin is known to decrease the synthesis of mevalonate, which is required for DNA synthesis (reviewed in 31,32 ), one would expect that epidermal DNA synthesis should be decreased. Yet, as observed here and elsewhere (30), the barrier abnormality in lovastatin-treated animals is accompanied by an increase in epidermal DNA synthesis. This provides further support for the linkage of barrier dysfunction and increased epidermal DNA synthesis.

Because of the association of hyperplastic dermatoses, such as EFAD, psoriasis, and the eczemas with abnormal barrier function $(33,34)$, it also is widely held that epidermal hyperplasia is not a normal physiologic response, but that it may instead provoke abnormal barrier function and disease manifestations $(33,35-39)$. Although our studies do not directly address the role of epidermal hyperplasia in disease pathogenesis, they do suggest alternatively that the epidermal hyperplasia that accompanies these diseases may be a consequence of a primary alteration of barrier function; i.e., they may represent an abortive attempt at barrier restoration.

Whereas prior studies have shown that transepidermal water loss is the regulatory signal for barrier repair, previously this signal had been linked solely to epidermal lipid biosynthesis (3-6). We have shown here that barrier perturbation is followed by a two-tiered response, the previously described, immediate burst in epidermal cholesterol and fatty acid synthesis, which largely returns to normal by $5-8 \mathrm{~h}(3,4)$ and several hours later by a burst in DNA synthesis. It is pertinent that, although barrier function returns towards normal in parallel with the lipid biosynthetic response, complete normalization of the barrier, even in the acetone model, requires over $30 \mathrm{~h}$ (3-5). Hence, the hyperplastic response may represent a latephase repair mechanism propelling an additional pool of cells, required for the final stages of barrier repair, into the outer strata of the epidermis. Moreover, the newly generated cells also represent an additional, potential source of lipid biosynthetic activity. Thus, it seems likely that epidermal hyperplasia is an important component of the process of barrier maintenance and repair.

Finally, it should be noted that occlusion partially corrected but did not completely normalize DNA synthesis in either of the acute models (Fig. 1, $A$ and $B$ ). Several factors, other than barrier function, are known to stimulate epidermal DNA synthesis. Cytokines and other growth factors (40), retinoids (41), tumor promoters, such as phorbol esters (42), ultraviolet irradiation (43), and extracellular calcium (44) represent examples that are well-known to regulate keratinocyte replication. Hence, it is likely that barrier requirements represent only one of several factors that regulate epidermal DNA synthesis.

\section{Acknowledgments}

Simon Jackson performed the protein biosynthesis studies, Barbara Brown provided technical assistance, and both William Chapman and Sally Michael provided editorial assistance.

These studies were supported by National Institutes of Health grant AR 19098 and the Medical Research Service, Veterans Administration. Dr. Proksch is a recipient of a grant from the Deutsche Forschungsgemeinschaft Bonn-Bad Godesberg, Germany, and the Paul G. Unna Foundation.

\section{References}

1. Elias, P. M. 1983. Epidermal lipids, barrier function, and desquamation. $J$. Invest. Dermatol. 80:44-49.

2. Williams, M. L., and P. M. Elias. 1987. The extracellular matrix of stratum corneum: role of lipids in normal and pathological function. CRC Crit. Rev. Ther. Drug Carrier Syst. 3:95-122.

3. Menon, G. K., K. R. Feingold, A. H. Moser, B. E. Brown, and P. M. Elias. 1985. De novo sterologenesis in the skin. II. Regulation by cutaneous barrier requirements. J. Lipid Res. 26:418-427.

4. Grubauer, G., K. R. Feingold, and P. M. Elias. 1987. The relationship of epidermal lipogenesis to cutaneous barrier function. J. Lipid Res. 28:746-752.

5. Grubauer, G., P. M. Elias, and K. R. Feingold. 1989. Transepidermal water loss: the signal for recovery of barrier structure and function. J. Lipid Res. 30:323-334.

6. Feingold, K. R., B. E. Brown, S. R. Lear, A. H. Moser, and P. M. Elias. 1986. The effect of essential fatty acid deficiency on cutaneous sterol synthesis. $J$. Invest. Dermatol. 87:588-591.

7. Pinkus, H. 1951. Examination of the epidermis by the strip method of removing horny layers. 1 . Observations on thickness of the horny layer and on mitotic activity after stripping. J. Invest. Dermatol. 16:383-386.

8. Williams, M. G., and R. Hunter. 1957. Studies on epidermal regeneration by means of the strip method. J. Invest. Dermatol. 29:407-413.

9. Fisher, L. B., and H. I. Maibach. 1972. Physical occlusion controlling epidermal mitosis. J. Invest. Dermatol. 59:106-108.

10. Fisher, L. B., and H. I. Maibach. 1972. The effect of occlusive and semipermeable dressings on the mitotic activity of normal and wounded human epidermis. Br. J. Dermatol. 86:593-600.

11. Menton, D. N. 1968. The effects of essential fatty acid deficiency on the skin of the mouse. Am. J. Anat. 122:337-355.

12. Lowe, N. J., and R. B. Stoughton. 1977. Essential fatty acid deficient hairless mouse: a model of chronic epidermal hyperproliferation. Br. J. Dermatol. 96:155-162.

13. McCullough, J. L., S. H. Schreiber, and V. H. Ziboh. 1978. Cell proliferation kinetics of epidermis in the essential fatty acid deficient rat. J. Invest. Dermatol. 70:318-320.

14. Wright, N. A. 1980. The kinetics of human epidermal cell populations in health and disease. In Recent Advances in Dermatology. Vol. 5. A. Rook and J. Savin, editors. Churchill-Livingstone, Inc., New York. 317-343.

15. Weinstein, G. D. 1987. Epidermal cell kinetics. In Dermatology in General Medicine. T. B. Fitzpatrick, A. Z. Eisen, K. Wolf, I. M. Freedburg, and K. F. Austen, editors. McGraw-Hill, Inc. New York. 154-165.

16. Uitto, J., A. Oikarinen, and A. J. Thody, 1986. Mechanical and physical functions of the skin. In Scientific Basis of Dermatology: A Physiological Approach. A. J. Thody and P. S. Friedman, editors. Churchill-Livingstone, Edinburgh. 6-25.

17. Montagna, W., and D. F. Parakkal. 1974. The Structure and Function of Skin. Academic Press, New York. 44-61.

18. Ebling, F. J. G., R. Marks, and A. Rook. 1986. The control of epidermopoiesis. In Textbook of Dermatology. A. Rook, D. S. Wilkinson, F. J. G. Eling, R. H. Champion, and J. L. Burton, editors. Scientific Publications Ltd., Oxford. 1407-1411.

19. King L. E, Jr. 1989. Introduction to diseases of the epidermis. In Clinical Dermatology. 16th revision. D. J. Demis, editor. J. B. Lippincott Co., Philadelphia. 1-12.

20. Elias, P. M., and B. E. Brown. 1978. The mammalian cutaneous perme- 
ability barrier: defective barrier function in essential fatty acid deficiency correlates with abnormal intercellular lipid deposition. Lab. Invest. 39:574-583.

21. Houtsmuller, U. M. T., and A. van der Beck. 1981. Effects of topical applications of fatty acids in essential fatty acid deficiency. Prog. Lipid Res. 20:219-224.

22. Elliott, W. J., H. Sprecher, and P. Needleman. 1985. Physiologic effects of columbinic acid and its metabolites on rat skin. Biochim. Biophys. Acta. 835:158-160.

23. Ziboh, V. A., and S. L. Hsia. 1972. Effects of prostaglandin $E_{2}$ on rat skin: inhibition of sterol ester biosynthesis and clearing of scaly lesions in essential fatty acid deficiency. J. Lipid Res. 13:458-467.

24. Hartop, P. J., and C. Prottey. 1976. Changes in transepidermal water loss and the composition of epidermal lecithin after applications of pure fatty acid triglycerides to skin of essential fatty acid-deficient rats. Br. J. Dermatol. 95:255264.

25. Lowe, N. J. 1977. Essential fatty acid deficient hairless mouse: the effects of topical agents on the epidermis. Br. J. Dermatol. 97:39-47.

26. Burton, K. 1968. Determination of DNA concentration with diphenylamine. Methods Enzymol. 12:163-166.

27. Boyce, S. T., and R. G. Ham. 1983. Calcium regulated differentiation of normal human keratinocytes in chemically defined clonal cultures and serumfree serial cultures. J. Invest. Dermatol. 81(Suppl.):33-40.

28. Imokawa, G. 1980. Comparative study on the mechanism of irritation by sulfate and phosphate type of anionic surfactants. J. Soc. Cosmet. Chem. 31:4566.

29. Alberts, A. W., J. Chen, G. Kuron, V. Hunt, J. Huff, and C. Hoffman. 1980. Mevinolin: a highly potent competitive inhibitor of hydroxymethyl-glutaryl-coenzyme A reductase and a cholesterol-lowering agent. Proc. Natl. Acad. Sci. USA. 77:3957-3961.

30. Feingold, K. R., M. Mao-Qiang, E. Proksch, G. K. Menon, B. Brown, and P. M. Elias. 1991. The lovastatin-treated rodent: characterization of a new model of barrier disruption and epidermal hyperplasia. J. Invest. Dermatol. 96:201-209.

31. Siperstein, M. D. 1984. Role of cholesterologenesis and isoprenoid synthesis in DNA replication and cell growth. J. Lipid Res. 25:1462-1468.
32. Goldstein, J. L., and M. S. Brown. 1990. Regulation of the mevalonate pathway. Nature (Lond.). 343:425-430.

33. Grice, K. A., and F. R. Bettley. 1967. Skin water loss and accidental hypothermia in psoriasis, ichthyosis, and erythroderma. Br. Med. J. 4:195-198.

34. Grice, K. A. 1980. Transepidermal water loss. In The Physiology and Pathophysiology of the Skin. A. Jarrett, editor. Academic Press Inc., New York. 2116-2146.

35. Van Scott, E. J., and T. M. Ekel. 1963. Kinetics of hyperplasia in psoriasis. Arch. Dermatol. 88:373-381.

36. Weinstein, G. D., and E. J. Van Scott. 1965. Autoradiographic analysis of turnover times of normal and psoriatic epidermis. J. Invest. Dermatol. 45:257262.

37. Spruitt, D., and K. E. Malton. 1968. Water vapour loss of psoriatic skin Br. Med. J. 1:180-182.

38. Petzoldt, D. G., O. Braun-Falco, and K. H. Wenig. 1970. Effect of plasticfoil-occlusion on psoriatic lesions. Arch. Klin. Exp. Dermatol. 238:160-168.

39. Anderson, T. F., and J. J. Voorhees. 1988. Psoriasis. In Pathogenesis of Skin Disease. B. H. Thiers and R. L. Dobson, editors. Churchill-Livingstone Inc. New York. 67-84.

40. Barbul, A., E. Pines, M. Caldwell, and T. K. Hunt, editors. 1987. Growth Factors and Other Aspects of Wound Healing. Progress in Clinical Biological Research. Vol. 266. Alan R. Liss, Inc., New York.

41. Fritsch, P., G. Pohlin, U. Langle, and P. M. Elias. 1981. Response of epidermal cell proliferation to orally administered aromatic retinoid. J. Invest. Dermatol. 77:287-291.

42. Marks, F., S. Bertsch, and G. Furstenberger. 1979. Ornithine decarboxylase activity, cell proliferation, and tumor promotion in mouse epidermis in vivo. Cancer Res. 39:4183-4188.

43. Schwartz, T., and T. A. Luger. 1989. Effect of UV irradiation on epidermal cell cytokine production. J. Photochem. Photobiol. B Biol. 4:1-13.

44. Hennings, H., D. Michael, C. H. Cheng, P. M. Steinert, K. A. Holbrook, and S. H. Yuspa. 1980. Calcium regulation of growth and differentiation of mouse epidermal cells in culture. Cell. 19:245-254. 